\title{
PENGARUH MODEL PEMBELAJARAN (STUDI LAPANGAN-PETA PIKIRAN) DAN MOTIVASI BERPRESTASI TERHADAP KETERAMPILAN MENULIS KARYA ILMIAH PEMBELAJARAN IPS SD MAHASISWA PGSD MUHAMMADIYAH KUPANG
}

\author{
Sunimbar ${ }^{1}$, Farid Fauzi Almu ${ }^{2}$ \\ Program studi PGSD, FKIP Universitas Muhammadiyah Kupang \\ sunimbar@gmail.com ${ }^{1}$
}

\begin{abstract}
Abstrak
Tujuan penelitian ini adalah (1) menguji perbedaan hasil belajar keterampilan menulis karya ilmiah pembelajaran IPS antara mahasiswa PGSD yang difasilitasi dengan model pembelajaran studi lapangan dan model pembelajaran peta pikiran; (2) menguji perbedaan hasil belajar keterampilan menulis karya ilmiah pembelajaran IPS antara mahasiswa yang memiliki motivasi berprestasi tinggi dan rendah; (3) menguji ada tidaknya interaksi antara model pembelajaran dengan motivasi berprestasi pada hasil belajar keterampilan menulis karya ilmiah makalah pembelajaran IPS. Rancangan penelitian ini adalah factorial non-equivalent control group design, dalam penelitian ini jumlah sampel adalah seluruh mahasiswa pendidikan guru sekolah dasar yang menempuh mata kuliah pembelajaran IPS SD pada semester genap T.A 2017/2018 sejumlah 65 orang, masing-masing terdiri atas 32 mahasiswa, mendapat perlakukan dengan model pembelajaran berbasis studi lapangan dan 33mahaiswa mendapat model pembelajaran berbasis peta pikiran.Berdasarkan analisis data, hasil penelitian dapat disimpulkan sebagai berikut: (1) pengunaan model pembelajaran berbasis studi lapangan secara signifikan lebih unggul dari pada model pembelajaran berbasis peta pikiran; (2) mahasiswa yang memiliki motivasi berprestasi tinggi menunjukkan nilai hasil belajar keterampilan menulis karya ilmiah signifikan lebih baik dari pada yang memiliki motivasi berprestasi rendah. (3) Tidak ada interaksi antara kelompok mahasiswa yang dibelajarkan menggunakan model pembelajaran dan motivasi berprestasi mahasiswa. Model pembelajaran tidak berpengaruh dengan motivasi berprestasi terhadap hasil belajar keterampilan menulis karya ilmiah mahasiswa.
\end{abstract}

Katakunci: model pembelajaran studi lapangan \& peta pikiran, motivasi berprestasi, hasil belajar, keterampilan menulis karya ilmiah.

Abstract

The purpose of this study were (1) to test the differences in learning outcomes of social science learning skills writing skills between PGSD students facilitated by field study learning models and mind map learning models; (2) testing the differences in learning outcomes of writing social science learning skills between students who have high and low achievement motivation; (3) examine whether there is an interaction between learning models and achievement motivation in learning outcomes of scientific writing skills in social studies learning papers The design of this research is factorial non-equivalent of control group design, in this study the number of samples is all students of Primary School Teacher Education who take the course of social science learning in the even semester of academic year 2017/2018 a number of 65 people, each consisting of 32 students, got treated with a field-based learning model and 33 students received a mind-based learning model. Based on the data analysis, the research results can be summarized as follows: (1)the use of field-based learning models is significantly superior to mind-based learning models; (2) students who have high achievement motivation shows the value of learning achievement of writing skills of scientific papers significantly better than those with low achievement motivation. (3) There is no interaction between groups of students who are taught using the learning model and achievement motivation of the students. The learning model does not affect the achievement motivation on the learning outcomes of students the skills to write scientific papers.

Keywords: Learning model on field study \& mind map, achievement motivation, learning result of writing skill on scientific work. 


\section{PENDAHULUAN}

Berdasarkan karakteristik konten pembelajaran IPS SD untuk membelajarkan mahasiswa Pendidikan Guru Sekolah Dasar, dapat dilakukan dalam kelas dan di luar kelas, dengan berbagai model pembelajaran. Bentuk pembelajaran yang tergambar dari awal sampai akhir yang disajikan secara khas oleh fasilitator, dinamakan model pembelajaran.Dalam merancang, melaksanakan, dan menilai pembelajaran IPS Terpadu, dapat dilakukan dengan berbagai model pembelajaran sesuai khas IPS Terpadu, antara lain model pembelajaran berbasis studi lapangan dan model pembelajaran berbasis peta pikiran.

Sintaks pembelajaran berbasis peta pikiran yang digunakan dalam penelitian ini adalah adaptasi dari Buzan. Hasil penelitian Olufunke (2014) menunjukkan bahwa hasil belajar kognitif pebelajar lebih tinggi dengan model pembelajaran berbasis peta pikiran daripada peta konsep (concept mapping). Selanjutnya, dikatakan bahwa membelajarkan si-belajar dengan menggunakan peta pikiran dapat meningkatkan keaktifan dan kreativitas berpikir si-belajar, memberikan semangat dan lebih menarik pada si-belajar, membantu si-belajar melihat makna materi pembelajaran secara komprehensif, belajar lebih efisien dan efektif, tidak menunjukkan fakta saja, tetapi menunjukkan konsep, prinsip, dan prosedur.

Selanjutnya, dikatakan bahwa membelajarkan si-belajar dengan menggunakan peta pikiran dapat meningkatkan keaktifan dan kreativitas berpikir si-belajar, memberikan semangat dan lebih menarik pada si-belajar, membantu si-belajar melihat makna materi pembelajaran secara komprehensif, belajar lebih efisien dan efektif, tidak menunjukkan fakta saja, tetapi menunjukkan konsep, prinsip, dan prosedur. Peta pikiran yang dirancang dapat membantu mahasiswa menulis karya ilmiah. David Clarence McClelland (1961) telah menampilkan teori motivasi berprestasi(achievment motivation theory), dikatakan bahwaindividu mempunyai cadangan energi potensial, bagaimana energi ini dilepaskan dan dikembangkan tergantung pada kekuatan atau dorongan motivasi individu dan situasi serta peluang yang tersedia. Menurut teori ini ada tiga jenis kebutuhan dasar manusia, yaitu: kebutuhan berprestasi ( $n$ Ach), kebutuhan berafiliasi ( $n$ Aff), dan kebutuhan berkuasa (nPow). Kebutuhan untuk berprestasi (n-Ach) bersifat intrinsik dan relatif stabil. Motivasi disini merupakan fungsi dari tiga variabel, yaitu (1) harapan untuk melakukan tugas dengan berhasil, (2) persepsi tentang nilai tugas dimaksud, (3) kebutuhan untuk keberhasilan atau sukses. 
Kebutuhan afiliasi (n-Aff) pada dasarnya identik dengan kebutuhan afiliasi Maslow. Orang merefleksikan keinginan untuk mempunyai hubungan-hubungan yang harmonis, kooperatif, dan sikap persahabatan dengan pihak lain. Orang yang memiliki kebutuhan afiliasi tinggi, pada umumnya berhasil dalam pekerjaan yang memerlukan interaksi sosial tinggi terutama jenis-jenis yang memerlukan hubungan antar perorangan yang bersifat kritikal bagi hasil pekerjaan.Kebutuhan akan kekuasaan ( $n$ - Pow) merupakan ekspresi dari keinginan seseorang individu untuk mengendalikan dan mempengaruhi pihak lain. Kebutuhan akan kekuasaan sangat dekat berhubungan dengan keinginan untuk mencapai suatu posisi kepemimpinan. Memperhatikan karakteristik subjek penelitian, maka indikator motivasi berprestasi yang digunakan dalam penelitian ini adalah pendapat Robinson (Cohen, 1976) yang dimodifikasi oleh Degeng (1991), adalah meliputi: (1) harapan untuk sukses, (2) kekuatiran akan gagal, (3) bekerja keras, dan (4) kompetisi.

Ada tiga pertanyaan dalam penelitian ini, yaitu: (1) apakah ada perbedaan hasil belajar keterampilan menulis karya ilmiah pembelajaran IPS SD antara mahasiswa yang difasilitasi dengan model pembelajaran studi lapangan dan model pembelajaran peta pikiran ?; (2) apakah ada perbedaan hasil belajar keterampilan menulis karya ilmiah antara mahasiswa PGSD dengan motivasi berprestasi tinggi dan rendah ?; (3) Apakah ada tidaknya interaksi model pembelajaran dengan motivasi berprestasi pada hasil belajar keterampilan menulis karya ilmiah pembelajaran IPS SD?.

Tujuan penelitian ini adalah (1) menguji perbedaan hasil belajar keterampilan menulis karya ilmiah pembelajaran IPS antara mahasiswa PGSD yang difasilitasi dengan model pembelajaran studi lapangan dan model pembelajaran peta pikiran; (2) menguji perbedaan hasil belajar keterampilan menulis karya ilmiah pembelajaran IPS antara mahasiswa yang memiliki motivasi berprestasi tinggi dan rendah; (3) menguji ada tidaknya interaksi antara model pembelajaran dengan motivasi berprestasi pada hasil belajar keterampilan menulis karya ilmiah makalah pembelajaran IPS.

\section{METODE PENELITIAN}

Rancangan penelitian ini menggunakan Quasi Experiment, yaitu designsfor whichit is impossible torandomlyas sign participants toall groups (Salkind,2006). Bentuk design Quasi Experiment yang digunakan dalam penelitian ini adalah: None quivalent Control-Group Design (Tuckman,1999). Peneliti menggunakan kelompok utuh (intac tgroup). 
Variabel yang menjadi fokus dalam penelitian ini, terdiri dari tiga macam variabel,yaitu: (1) Variabel Bebas (independent variables),dalam penelitian ini adalah penggunaan model pembelajaran yang terdiri dari dua dimensi, yaitu model pembelajaran berbasis studi lapangan dan model pembelajaran berbasis peta pikiran. (2) Variabel Terikat (dependent variables), yaitu hasil belajar keterampilan menulis karya ilmiah (makalah). (3) Variabel moderator adalah tingkat motivasi berprestasi yang terdiri dari dua dimensi, motivasi berprestasi tinggi dan motivasi berprestasi rendah. Hubungan antar variabel penelitian disajikan pada Gambar 1.

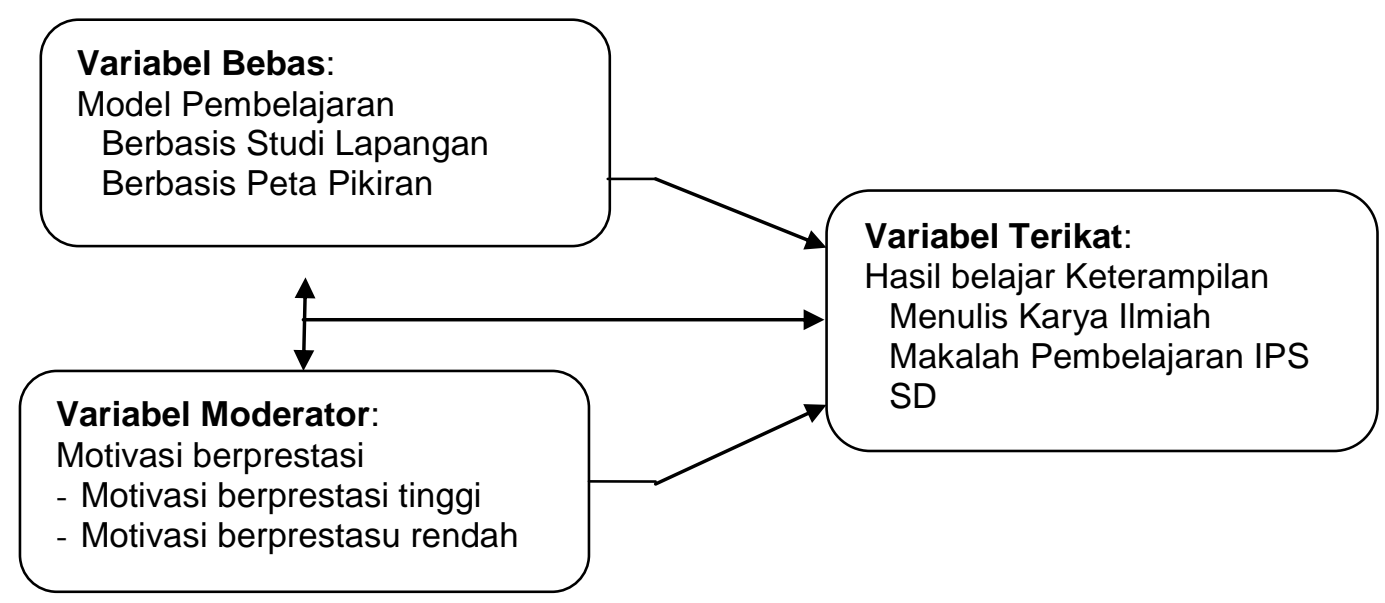

Gambar 1 Hubungan Antarvariabel Penelitian

Penelitian ini menggunakan dua jenis instrumen, yaitu: (1)instrumen yang digunakan untuk mengukur tingkat tinggi rendahnya motivasi berprestasi mahasiswa sebagai variabel moderator dan (2) instrumen yang digunakan untuk mengukur hasil belajar keterampilan menulis karya ilmiah pembelajaran IPS SD sebagai variabel terikat.

Hasil uji total reliabilitas instrumen penelitian dengan Alpha Cronbach 0.935. Hasil ini dinyatakan handal karena $>0.6$.Berdasarkan uji asumsi dalam analisis faktor ditemukan uji asumsi motivasi berprestasi memiliki nilai indeks Kaiser-Meyer-Olkin (KMO) sebesar 0.918 adalah lebih besar daripada 0.5 sehingga dianggap telah memenuhi syarat untuk menunjukkan adanya kecukupan ukuran kedekatan sampel. Instrumen motivasi berprestasi yang telah diuji validasi dan reliabilitas maka dilakukan uji rotasi komponen matriks. Hasil dari uji tersebut membentuk 4 komponen (strive, performance, challenge, goaloriented) dengan nilai varian equievalen kumulatif 
mencapai $81.21 \%$.

Sesuai dengan jenis variabel penelitian teknik analisis data yang digunakan adalah ANOVA(Analisys of variance) dua jalur $2 \times 2$. Semua pengujian dan analisis data dalam penelitian ini menggunakan program komputer SPSS Statistik versi 24.0 for windows.

\section{HASIL DAN PEMBAHASAN}

Subjek penelitian ini adalah mahasiswa semester IV PGSD FKIP Universitas Muhammadiyah Kupang Semester Genap Tahun Akademik 2017/2018 yang memprogramkan mata kuliah pembelajaran IPS SD. Deskripsi umum hasil penelitian didasarkan atas hasil analisis deskriptif subyek penelitian yang berjumlah 65 mahasiswa, yang terbagi menjadi 32 mahasiswa difasilitasi menggunakan model pembelajaran berbasis studi lapangan dan 33 mahasiswa dalam kelompok kontrol yang difasilitasi dengan menggunakan model pembelajaran berbasis peta pikiran.

Sebaran subjek penelitian dari mahasiswa PGSD di berikan angket motivasi berprestasi yang dikelompokkan menjadi dua dimensi, yaitu motivasi berprestasi tinggi dan motivasi berprestasi rendah. Sebaran subjek penelitian berdasarkan motivasi berprestasi disajikan pada tabel 1 .

Tabel 1 Sebaran Subyek Penelitian berdasarkan Motivasi Berprestasi

\begin{tabular}{cccc}
\hline No. & Motivasi Berprestasi & F & Persentase \\
\hline 1. & Tinggi & 36 & 55,00 \\
2. & Rendah & 29 & 44,00 \\
\hline
\end{tabular}

Sebaran subyek penelitian berdasarkan model pembelajaran dan motivasi berprestasi digabungkan dalam bentuk tabulasi silang (crosstabs), maka distribusi jumlah subjek penelitian untuk setiap kelompok perlakuan dapat ditampilkan pada tabel 2.

Tabel 2 Sebaran Subyek Penelitian berdasarkan Model Pembelajaran \& Motivasi Berprestasi

\begin{tabular}{|c|c|c|c|c|}
\hline \multicolumn{2}{|c|}{ Model Pembelajaran } & \multirow[t]{2}{*}{ Total } & & \\
\hline \multirow[t]{2}{*}{ Studi Lapangan } & Peta Pikiran & & & \\
\hline & Rendah & $10(34,84)$ & $19(65,16)$ & 29 \\
\hline \multicolumn{5}{|l|}{ Motivasi Berprestasi } \\
\hline & Tinggi & $22(65,16)$ & $14(34,84)$ & 36 \\
\hline \multicolumn{2}{|c|}{ Total } & $32(100,00)$ & $33(100,00)$ & $\begin{array}{ll}65 & 100,00)\end{array}$ \\
\hline
\end{tabular}


Instrumen hasil belajar keterampilan menulis karya ilmiah pembelajaran IPS SD digunakan lembar penilaian produk makalah: penulisan abstrak dan kata kunci, bagian pendahuluan, penulisan teks utama, penutup, bahan rujukan. Berdasarkan skor tertinggi dan terendah, ditetapkan dua kategori kelompok mahasiswa: (1) kelompok mahasiswa yang memiliki keterampilan menulis karya ilmiah makalah pembelajaran IPS SD tinggi $($ skor $=70-80)$ dan keterampilan menulis karya ilmiah makalah pembelajaran IPS SD rendah $($ skor $=50-69)$.

Data hasil pretest mahasiswa yang difasilitasi menggunakan model pembelajaran berbasis studi lapangan dan mahasiswa difasilitasi dengan model pembelajaran berbasis peta pikiran, disajikan pada tabel 3 .

Tabel 3 Data Hasil Pretest

\begin{tabular}{cccccc}
\hline \multicolumn{2}{c}{ Model Pembelajaran } & N & Mean & Std.Deviation & Std. Error mean \\
\hline \multirow{2}{*}{ Pretest } & Studi Lapangan & 32 & 41,09 & 5,336 & 0,943 \\
& & & & & 0,986 \\
\hline
\end{tabular}

Berdasarkan pengujian varians menunjukkan bahwa nilai uji Levene sebesar 0.108 dengan nilai signifikansi (p) sebesar 0.610 ( $p>0.05$ ), maka dapat disimpulkan bahwa ragam data hasil belajar keterampilan menulis karya ilmiah makalah pembelajaran IPS SD mahasiswa PGSD adalah homogen. Berdasarkan hasil uji t independent menunjukkan nilai signifikansi untuk hasil belajar keterampilan menulis karya ilmiah (makalah) pembelajaran IPS SD mahasiswa PGSD antara kelompok model pembelajaran berbasis studi lapangan dan model pembelajaran berbasis peta pikiran sebesar 0.173 ( $p>0.05$ ), yang berarti bahwa hasil belajar keterampilan menulis karya ilmiah makalah pembelajaran IPS mahasiswa PGSD (pretest) antara kelompok studi lapangan dan kelompok peta pikiran menunjukkan tidak adanya perbedaan yang signifikaan ( $p>0.05$ ). Hal ini berarti kedua kelompok memiliki kemampuan yang setara.

Data hasil skor posttest hasil belajar keterampilan menulis karya ilmiah (makalah) pembelajaran IPS SD mahasiswa PGSD yang difasilitasi menggunakan model pembelajaran berbasis studi lapangan dan yang difasilitasi dengan model pembelajaran berbasis peta pikiran menunjukkan bahwa nilai rata-rata dengan menggunakan model pembelajaran studi lapangan dengan motivasi berprestasi tinggi (rerata $=76.74 \pm \mathrm{SD}$ 12.41) lebih besar dari skor nilai dengan menggunakan model pembelajaran berbasis peta pikiran (rerata $=68.65 \pm 10.96)$ dengan motivasi berprestasi yang rendah (rerata $=68.65$ 
\pm SD10.96). Adapun nilai rata-rata dengan menggunakan model pembelajaran studi lapangan dengan motivasi berprestasi tinggi (rerata77.27 \pm SD12.02) lebih besar dari pada nilai rata-rata dengan menggunakan model pembelajaran peta pikiran dengan motivasi berprestasi rendah (rerata69.64 \pm SD 13.48). Berdasarkan rata-rata hasil belajar keterampilan menulis karya ilmiah makalah mahasiswa yang mempunyai motivasi berprestasi tinggi (rerata 73.6 \pm 12.55 ) lebih tinggi daripada rata-rata hasil belajar keterampilan menulis karya ilmiah makalah pembelajaran IPS SD mahasiswa yang mempunyai motivasi berprestasi rendah (rerata $65.5 \pm 12.58$ ).

Berdasarkan pengujian normalitas data dengan menggunakan Uji KolmogorovSmirnov,menunjukkan nilai signifikansi 0.382 , dan $0.784(\mathrm{p}>0,05)$ untuk data hasil belajar keterampilan menulis karya ilmiah makalah pembelajaran IPS SD mahasiswa PGSD pretest dan posttet .Hal ini disimpulkan bahwa data hasil belajar keterampilan menulis karya ilmiah makalah pembelajaran IPS SD mahasiswa PGSD pretest dan posttest tersebut menyebar normal.

Homogenitas yang diperoleh memiliki nilai Sign (p) dari uji Levene sebesar 0.877 dan lebih besar dari alpha 0.05 ,maka dapat disimpulkan bahwa ragam data nilai hasil belajar keterampilan menulis karya ilmiah makalah pembelajaran IPS SD mahasiswa PGSD (posttest) untuk kelompok perlakuan PS-MBr, PS-MBt, PL-MBr, dan PL-MBt relatif homogen. Berdasarkan hasil analisis ragam, dapat diketahui bahwa berdasarkan model pembelajaran menunjukkan nilai signifikansi sebesar 0.010( $\mathrm{p}<0,05)$,sehingga disimpulkan bahwa terdapat perbedaan yang signifikan antara model pembelajaran studi lapangan dan model pembelajaran peta pikiran.

Adapun perbandingan nilai rata-rata skor nilai untuk interaksi antara model pembelajaran dan tingkat motivasi berprestasi menunjukkan nilai signifikansi sebesar 0.922( $>00,05)$, disimpulkan bahwa tidak terdapat perbedaan yang signifikan pada interaksi antara model pembelajaran dan tingkat motivasi berprestasi. Adanya perbedaan nilai rata-rata hasil belajar keterampilan menulis karya ilmiah makalah pembelajaran IPS SD mahasiswa PGSD (posttest) sebagai pengaruh dari setiap kelompok perlakuan tersebut dapat dilihat pada Gambar 2. 


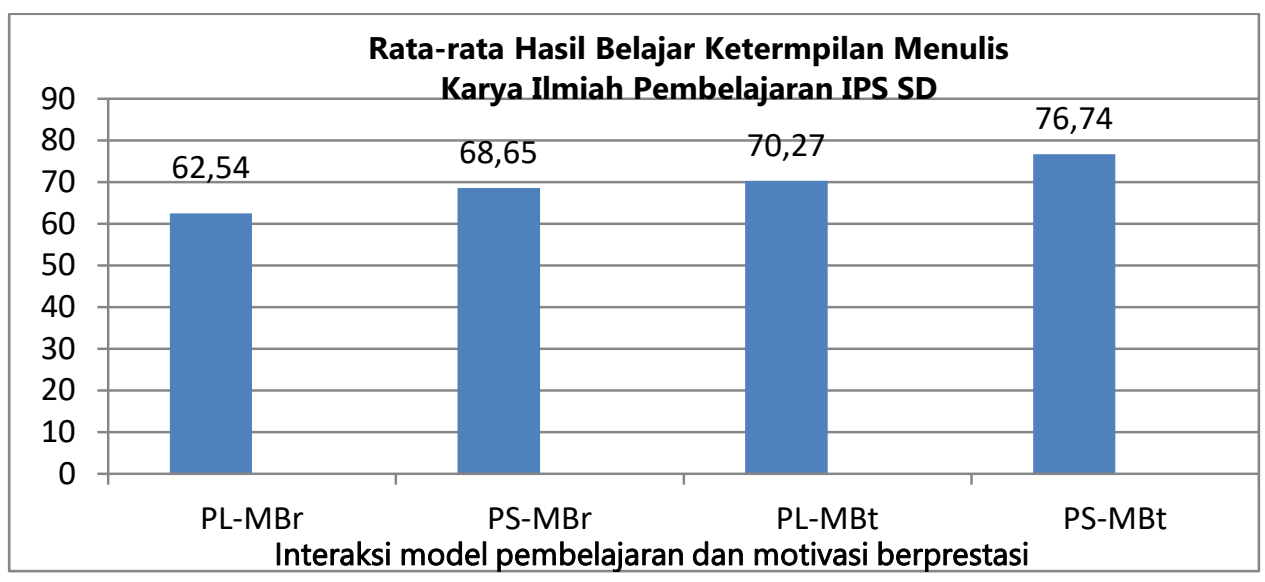

Grafik 1 PerbandinganNilaiRerata Hasil BelajarKeterampilan Menulis

Gambar 2 menunjukkan besarnya pengaruh dari setiap kelompok perlakuan terhadap nilai rata-rata hasil belajar keterampilan menulis karya ilmiah pembelajaran IPS SD mahasiswa PGSD (posttest). Perbandingan nilai rata-rata hasil belajar keterampilan menulis karya ilmiah pembelajaran IPS SD mahasiswa PGSD dan motivasi berprestasi menunjukkan nilai signifikansi sebesar $0.001(\mathrm{p}<0,05)$, sehingga dapat disimpulkan bahwa terdapat perbedaan yang signifikan pada nilai rata-rata hasil belajar keterampilan menulis karya ilmiah makalah pembelajaran IPS SD antara mahasiswa yang mempunyai motivasi berprestasi tinggi dan motivasi berprestasi rendah.

Tabel 4 RingkasanHasil UjiAnova

TestsofBetween-SubjectsEffects Dependent Variable:

Hasil Belajar Keterampilan Menulis Karya Ilmiah Pembelajaran IPS

Mahasiswa PGSD

\begin{tabular}{|c|c|c|c|c|c|}
\hline Source & $\begin{array}{l}\text { TypellISum } \\
\text { ofSquares }\end{array}$ & $\begin{array}{l}d \\
f\end{array}$ & $\begin{array}{l}\text { Mean } \\
\text { square }\end{array}$ & $\mathrm{F}$ & $\begin{array}{l}\mathrm{Si} \\
\mathrm{g}\end{array}$ \\
\hline CorrectedModel & $2807.184^{a}$ & 3 & & & .00 \\
\hline Intercept & 519564.629 & 1 & 519564.629 & 3448.704 & 1 \\
\hline Model.pembelajara & 1046.063 & 1 & 1016062 & & .00 \\
\hline$\frac{n}{n}$ & 1656.985 & 1 & 1046.063 & 6.943 & 0 \\
\hline $\begin{array}{l}\text { Motivasi.berpresta } \\
\text { si Model }\end{array}$ & 1.439 & & 1656.985 & & .01 \\
\hline pembelajaran & 15818.780 & 1 & 1139 & 10.999 & 0 \\
\hline * Motivasi.berprestasi & 553006.000 & 105 & 1.439 & .0 & 1 \\
\hline Error & 18625.963 & 109 & 150.655 & 1 & .92 \\
\hline $\begin{array}{r}\text { Total } \\
\text { CorrectedTotal }\end{array}$ & & 108 & & & 2 \\
\hline
\end{tabular}

Berdasarkan hasil pengujian hipotesis pada penelitian ini menunjukkan bahwa angka p-value $0.922(\mathrm{p}>0,05)$ pada table 1, sehingga Ho diterima karena tidak terdapat 
perbedaan yang bermakna (signifikan), sehingga dapat disimpulkan tidak ada interaksi antara penggunaan model pembelajaran dan tingkat motivasi berprestasi.

Tidak adanya interaksi antar dua variabel mengindikasikan bahwa kedua variabel (model pembelajaran dan motivasi berprestasi) memberikan pengaruh yang sama kuat seperti yang dikemukakan oleh Hair et al., (1995).Temuan penelitian ini sesuai dengan De Caro, et al. (2013) menyatakan bahwa adanya pengaruh utama yang kuat sehingga melemahkan interaksi yang ada.

Lebih tinggi skor mahasiswa yang di fasilitasi dengan model pembelajran studi lapangan di dukung dengan penelitian yang telah di lakukan oleh Rosenfeld (1994) menemukan pembelajaran mahasiswa geografi melalui studi lapangan melalui pengamatan dan atau disertai wawancara terhadap berbagai fenomena geosfer atau fenomena permukaan bumi (dimensi fisik dan dimensi manusia) lebih unggul dalam hal: tidak hanya perolehan hasil belajar kognitif, aktivitas, dan kreativitas mahasiswa, tetapi juga keterampilan dan keberanian berpendapat, menulis karya ilmiah, berdebat, dan memberikan suatu solusi terhadap masalah yang ditemukan mahasiswa dibanding dengan pembelajaran konvensional di kelas, kendatipun pembelajaran di kelas tersebut menggunakan media.

\section{KESIMPULAN DAN SARAN}

Ada perbedaan hasil belajar keterampilan menulis karya ilmiah makalah pembelajaran IPS SD mahasiswa PGSD yang signifikan antara kelas yang difasilitasi dengan model pembelajaran berbasis studi lapangan dan model pembelajaran berbasis peta pikiran. Ada perbedaan hasil keterampilan menulis karya ilmiah pembelajaran IPS SD mahasiswa PGSD yang signifikan antara mahasiswa yang mempunyai motivasi berprestasi tinggi dengan mahasiswa yang mempunyai motivasi berprestasi rendah.Tidak ada interaksi antara model pembelajaran dan motivasi berprestasi terhadaphasil belajar keterampilan menulis karya ilmiah makalah.

Agar perbedaan motivasi berprestasi mahasiswa dapat terakomodir dalam membelajarkan mahasiswa pada studi lapangan maka fasilitator perlu memberikan perhatian dan fasilitas yang sesuai dan memberikan motivasi kepada setiap mahasiswa sesuai dengan kebutuhan mereka. Fasilitator perlu memperbaiki rancangan, pelaksanaan dan evaluasi model pembelajaran studi lapangan, memberikan motivasi terhadap pebelajar yang mempunyai motivasi berprestasi rendah. Untuk melihat kefektifan pemanfaatan model pembelajaran studi lapangan lebih lanjut dapat melibatkan variabel- 
variabel lain seperti: minat, sikap, gaya belajar, latar belakang mahasiswa, dan lain-lain. Untuk penelitian selanjutnya dapat pula dicoba pada mata kuliah keahlian yang lainnya.

\section{DAFTAR PUSTAKA}

Adodo, S.O., 2013, Effect of Mind-Mapping as a Self-Regulated Learning Strategy on Students Achievement in Basic Science and Technology, Mediterranean Journal of Social Sciences, Published by MCSER-CEMAS-Sapienza University of Rome, 4 (6) : 163-172.

Cohen, L., 1976, Educational Research in Classroomm and School: A Manual ofMaterials and Methods, San Fransisco: Harper \& Row.

Day, R.A.,(1989), Haw to Write and Publish a Scientific Paper, Cambrige: Cambrige University Press.

Degeng, I Nyoman Sudana., (1991), Karakteristik Belajar Mahasiswa Berbagai Perguruan Tinggi di Indonesia, Jakarta: PAU-UT Dirjen Dikti Depdikbud.

DeCaro,D.A.,DeCaro,M.S.,Johnson,B.R.2013,Achievement Motivation andStrategy Selection During Exploratory Learning. Departement of Psychology and Human Development. VanderbiltUniversityNashville.USA:370-375.

Glenn, David dan D. Dickman, (2009), Forestry Field Study: A Manual for ScienceTeacher, Arlington Virginia: NSTA Press.

Hair, J.F., Anderson, R.E., Tatham R.I \& Back, W.C., (1995). Multivariate Data Analyze with Reading, $4^{\text {th }}$ ed). New Jersey: Prentice-Hall, Inc.

Yoshimizu, Hiroya., (2015), Trends in Japanese Geography Education Research in Recent Years, in.

Yoshiyasu Ida (ed.), Geography Education in Japan, Tokyo: Springer, 175-184.

Junqing, Fu ,2011,The Relationships among Self-Efficacy, Achievement Motivation, and Work Values for Regular Four Year University Studentsand Community College Studentsin China. Dissertation.UniversityofIllinoisatUrbana-Champaign.

McClelland, D.C., (1967), The Achieving Sociey, New York: The Free Press.

Oufunke, B.T. \& Blessing, O. O. (2014). "Achievement in Physics Using Mastery Learning and Mind Mapping Approaches: Implication on Gender and Attitude". International Journal of Humanities, Social Sciences and Education (IJHSSE), 1 (12), 154-161.

Suprapto, Edy., 2014, Pengaruh Model Pembelajaran Kontekstual Vs Pembelajaran Langsung dan Motivasi Berprestasi Terhadap Hasil Belajar Kognitif dan 
Keterampilan Motorik di SMK Negeri 2 Kupang, Disertasi, tidak diterbitkan, Malang: Ps UM.

Singh, K., 2011, Study of Achievement Motivation in Relation to Academic Achievement of Students, International Journal of Educational Planning\&Administration, 1 (2): 161-171.

Tilbury, D., dan Williams M., 1997, Teaching and Learning Geography, London: Routledge. Tim Revisi PPKI. 2012. Pedoman Penulisan Karya Imiah. Malang: UM Press.

Tuckman, B.W., (1999), Conducting Educational Research, $5^{\text {th }}$ ed., Orlando: EarlMcpeek Publisher 